ROCZNIKI HUMANISTYCZNE

Tom LXVIII, zeszyt $10 \quad-\quad 2020$

DOI: http://dx.doi.org/10.18290/rh206810-9

MARIA MOCARZ-KLEINDIENST

\title{
GATUNEK FILMOWY JAKO OBIEKT PRZEKŁADU - IMPLIKACJE DYDAKTYCZNE
}

\section{WPROWADZENIE}

W dobie dynamicznego rozwoju technologii informacyjnych i potrzeb poszerzania horyzontów poznawczych o nowe doświadczenia kulturowe - również te przekazywane za pośrednictwem obrazów filmowych - rośnie liczba dokonywanych przekładów, a wraz z nią liczba prac naukowych z przekładu audiowizualnego w roli głównej. Od dawna w centrum zainteresowań badaczy są techniki przekładu audiowizualnego, językowe i kulturowe zjawiska w przekładzie, metody analizy translatorskiej tekstów audiowizualnych (Delebastita; Gambier, Gottlieb; Díaz-Cintas; Reinart; Tomaszkiewicz; Garcarz; Szarkowska, „Przekład” i Forms; Bogucki, Areas; i in.). Potrzeba profesjonalizacji usług $\mathrm{w}$ sektorze thumaczeniowym spowodowała wyraźny wzrost zainteresowania specjalizacją translatorską na studiach filologicznych i lingwistycznych, także w zakresie przekładu audiowizualnego. W akademickiej dydaktyce przekładu uwaga jest skoncentrowana na potrzebie przyswojenia przez studentów strategii i sposobów tłumaczenia, podporządkowanych językowym i technicznym wymogom podstawowych technik tłumaczeń filmowych: napisów, wersji lektorskiej oraz dubbingu (Gottlieb 161; McLoughlin; Kaczmarek 74). W ciągu ostatnich kilku lat obserwuje się także zwiększone zainteresowanie zagadnieniami dydaktyki przekładu intersemiotycznego, głównie audiodeskrypcji (np. Chmiel i Mazur). Wyraźnie brakuje natomiast - zarówno w samej translatoryce audiowizualnej ${ }^{1}$, jak i w dydaktyce prze-

Dr hab. Maria Mocarz-Kleindienst, prof. KUL - Katolicki Uniwersytet Lubelski Jana Pawła II, Instytut Językoznawstwa, Katedra Translatoryki i Języków Słowiańskich; e-mail: momar@kul.pl. ORCID: https://orcid.org/0000-0002-2205-5470.

${ }^{1}$ Wyjątek stanowi monografia Agaty Hołobut i Moniki Woźniak, w której autorki przeanalizowały brytyjskie i amerykańskie produkcje historyczne pod kątem strategii ich przekładu na język polski i włoski. 
kładu audiowizualnego - zainteresowania problematyką strategii przekładu w kontekście genologii gatunków filmowych. Tymczasem epoka tzw. zwrotu audiowizualnego nieustannie dostarcza nowych produkcji filmowych, przypisanych najczęściej do konkretnych gatunków filmowych.

\section{POJĘCIE GATUNKU FILMOWEGO}

W niniejszych badaniach punktem wyjścia jest założenie, że przekład filmowy jest ze swej natury procesem niejednorodnym, zróżnicowanym, nie tylko poprzez stosowanie różnych technik przekładu (wersja lektorska, dubbing, napisy), ale także wskutek przynależności filmów do różnych gatunków. Powołując się na definicję gatunku filmowego, zaproponowaną przez Krzysztofa Loskę, przyjmuję na potrzeby niniejszego opracowania, że gatunek filmowy to

zespół wzorców i konwencji - narracyjnych czy ikonograficznych - wykorzystywany przez twórców $\mathrm{w}$ celu przypisania obrazom określonych znaczeń oraz nawiązania umowy komunikacyjnej z publicznością. Rozpoznanie przynależności gatunkowej pozwala na zrozumienie znaczenia oraz ustalenie związku z innymi tekstami. Ważną rolę odgrywa system oczekiwań, który umożliwia widzowi oswojenie filmu poprzez umieszczenie go we właściwych ramach. (Loska 72-73)

Gatunki filmowe podlegają ewolucji, m.in. wskutek procesów globalizacyjnych, rozwoju myśli estetycznej oraz pod wpływem technologii służących jako narzędzie przekazu nowych idei i koncepcji kulturowych. W „gatunkowej dżungli" (in the genre jungle) ${ }^{2}$ produkcji filmowych, w celu ułatwienia periodyzacji, zachowania porządku i funkcjonalności bogatej oferty kinematograficznej, uzasadnione jest jednak operowanie pojęciem gatunku filmowego jako podstawowej operacyjnej, funkcjonalnej jednostki taksonomii filmoznawczej, porządkującej system dynamicznie rozwijającej się kinematografii. Praktyka marketingu filmowego pokazuje, że każdy opis filmu zawiera informacje na temat jego przynależności gatunkowej. Jest to ważki argument za tym, żeby w procesie podejmowania decyzji translatorskich uwzględniać cechy gatunkowe tłumaczonego filmu. Odbiorca takiego przekładu powinien otrzymać film z identycznym zestawem cech gatunkowych.

\footnotetext{
${ }^{2}$ Taką metaforą posłużyła się Raphaëlle Moine w monografii poświęconej gatunkom filmowym (Moine 24).
} 


\section{ZAŁOŻENIA METODOLOGICZNE \\ I DOBÓR MATERIAŁU BADAWCZEGO}

Analogicznie do istniejących typologii przekładu, wykorzystujących kryterium gatunków tekstów werbalnych (tj. literackich, użytkowych, specjalistycznych), należy przyjąć, że także przekład różnych gatunków filmowych wymaga od tłumacza odrębnego podejścia do każdego gatunku, strategicznego myślenia, wnikliwej analizy materiału filmowego (werbalnego i wizualnego), uważnego spojrzenia na słowo, obraz i dźwięk w przekładzie jako komponenty estetyki i budulce schematów fabularnych dzieła filmowego. Te aspekty analizy materii filmowej powinny być włączone także w proces dydaktyki przekładu filmowego. Stąd też głównym celem podjętych badań jest wskazanie na potrzebę uwzględnienia $\mathrm{w}$ procesie dydaktyki cech gatunkowych filmu jako obiektu działań translatorskich. Kolejnym, wynikającym z poprzedniego, celem jest próba odpowiedzi na pytanie, w jaki sposób można sprostać w procesie przekładu dwóm wymogom: zachowania cech gatunkowych thumaczonego filmu przy jednoczesnym dostosowaniu się do wytycznych formalnych zleconej techniki przekładu filmowego (w danym wypadku wersji lektorskiej). Tak sprofilowany cel badań wyznacza określone zadania. Należą do nich: 1) ustalenie najważniejszych cech gatunkowych filmu, będących podstawą tzw. inwariantu intersemiotycznego, który powinien być odtworzony w przekładzie, 2) analiza istniejących rozwiązań translatorskich, zogniskowana na zachowaniu takiego inwariantu z wykorzystaniem techniki wersji lektorskiej, 3) propozycja praktycznych zastosowań wytycznych gatunkowych w akademickiej dydaktyce przekładu filmowego. Przyjęta metoda ma charakter opisowo-preskryptywny, łączy analizę dwutekstu (tj. filmu oryginalnego i jego przekładu) z wnioskami aplikatywnymi dla procesu dydaktycznego. Będzie to studium przypadku, realizacja wymienionych zadań będzie się sprowadzać do analizy jednego gatunku filmowego - filmu katastroficznego. W charakterze materiału ilustracyjnego wybrano obraz Metro z 2010 r. w reżyserii Antona Miegierdiczewa w oryginalnej, rosyjskiej wersji językowej z polską wersją lektorską. Jest to najczęściej stosowana w Polsce technika tłumaczenia filmów i seriali na potrzeby telewizji. Jej istotą jest opracowanie przez tłumacza wersji językowej, następnie nagranej w studiu przez lektora i nałożonej na wyciszoną ścieżkę oryginalną ${ }^{3}$. Nie bez powodu wybrano film prezentowany na filmowym kanale TVP Kultura z profesjonalnie przygotowaną wersją tłumaczoną, której autorką

\footnotetext{
${ }^{3}$ Szerzej na ten temat w pracy Adamowicz-Grzyb 17-20 i in.
} 
jest Krystyna Łozowska. Materiał ma bowiem na celu zaprezentowanie szerokiego spektrum konkretnych rozwiązań translatorskich, zaproponowanych przez doświadczoną tłumaczkę.

\section{CECHY GATUNKOWE FILMU \\ JAKO PODSTAWA INWARIANTU INTERSEMIOTYCZNEGO}

Podstawą wyodrębnienia gatunku filmu katastroficznego jest tematyka, koncentrująca się wokół zjawiska katastrofy i walki z żywiołem, np. ogniem (Płonacy wieżowiec), huraganem (Twister), trzęsieniem ziemi (San Francisco) czy wodą (Tragedia Posejdona) ${ }^{4}$. Ten ostatni żywioł stanowi również bazę rozwoju akcji filmu Metro. Rozgrywa się ona w tunelu moskiewskiego metra, w którym dochodzi - wskutek nadmiernej rozbudowy centrum miasta - do pęknięcia jednej ze ścian, w wyniku czego szczelinami bardzo szybko wdziera się do stacji woda, paraliżując ruch komunikacyjny w tunelu i wywołując panikę uwięzionych w wagonach pasażerów. Wśród nich jest m.in. lekarz Andriej Garin, wiozący córkę Ksenię do szkoły, a także kochanek jego żony, zmuszony, z powodu awarii samochodu, do skorzystania z tego środka transportu. Filmy katastroficzne wyróżnia tendencja do prezentowania sugestywnych scen niszczycielskiej siły żywiołu, zorganizowanej walki z nim służb ratowniczych oraz walki o przetrwanie grupy bohaterów, przypadkowo wchłoniętych $\mathrm{w}$ otchłań nadciągającego huraganu, powodzi lub innej klęski żywiołowej. $Z$ reguły są to filmy wysokobudżetowe $\mathrm{z}$ efektami specjalnymi, osiąganymi dzięki zastosowaniu technik komputerowych. Względnie ustabilizowana konwencja ikonograficzna filmu katastroficznego współgra ze strukturą narracji werbalnej, tworząc inwariant intersemiotyczny filmu katastroficznego jako sumę znaczeń nadawanych przez słowo i obraz. Dominujący w swej sile obraz żywiołu lub klęski w filmie katastroficznym skłania do uznania komponentu wizualnego za wyraźnie dominujący nad warstwą słowną. W tej ostatniej już w pierwszych kadrach filmu można zauważyć słowa-klucze jako zapowiedź zbliżającej się katastrofy. W filmie Metro słowem zapowiadającym katastrofę i pojawiającym się już w pierwszych minutach dialogu filmu jest woda: najpierw jej brak w kranie w mieszkaniu lekarza (zauważa to jego córka Ksenia/Ksiusza), następnie wydobywająca się kroplami z pękniętej ściany czy wreszcie, w kolejnych kadrach, zmieniająca się w trudny do opanowania żywioł (w transkrypcji filmu odno-

\footnotetext{
${ }^{4}$ Przykłady przytaczam za K. Loską (95).
} 
towano 40 użyć tego słowa). W punkcie kulminacyjnym filmu, kiedy maszynista wagonu traci panowanie nad kierownicą wskutek napierającej niszczycielskiej siły żywiołu i w konsekwencji wagon metra wykoleja się, pasażerowie zaś mimowolnie są przerzucani od jednej ściany wagonu do drugiej, w filmie milkną dialogi. Katastrofę rejestruje wyłącznie obraz kamery i oko widza. Wnikliwe ucho jest $\mathrm{w}$ stanie usłyszeć jedynie pojękiwania ludzi. Semantykę żywiołu dobitnie przekazuje obraz, dynamicznie zmieniające się kadry, przeplatające się z długimi ujęciami kamery, rejestrującej zastygłych w swej niemocy fizycznej przerażonych pasażerów. Wciągnięci w wir żywiołu pechowi pasażerowie wagonu metra, szarpani skrajnymi emocjami: od niepokoju poprzez strach, panikę czy wreszcie zwątpienie w uzyskanie zbawczej pomocy, wypowiadają repliki silnie nacechowane emocjonalnie. Są w nich zatem zawołania osób im towarzyszących, liczne powtórzenia z prośbą o pomoc, ratunek lub kategoryczne żądania podjęcia lub zaniechania działań czy wreszcie przekleństwa. Potwierdzają to poniższe przykłady w tabeli:

Tabela 1. Rozmowy między pasażerami w metrze

[K: Ksenia, AG: Andriej Garin, A: Alisa, D: Denis, P: Pasażer, S: Siergieicz, G: Gałoczka, 0 : Głosy z oddali]

\begin{tabular}{|c|c|c|c|}
\hline $\mathrm{Nr}$ & $\begin{array}{c}\text { Kod czasowy } \\
\text { wejścia }\end{array}$ & Wersja rosyjska & Polska wersja lektorska ${ }^{5}$ \\
\hline 1. & {$[42: 20]$} & $\begin{array}{l}\text { [K] - Ой, мамочка, спаси! } \\
\text { [AG] - Ксюша! Ксюша! Ксюша! } \\
\text { [A] - Почему это? } \\
\text { [AG] - Ксюша! Ксюша! Ксюша! } \\
\text { [D] - Что случилось? Нас взорвали? }\end{array}$ & $\begin{array}{l}\text { - Zostaw to! } \\
\text { - Co się stało? Bomba? }\end{array}$ \\
\hline 2. & [46:39] & $\begin{array}{l}\text { [0] - Ксюша! Наташа! } \\
\text { [D] - Пойдем! Ты идти можешь? } \\
\text { [0] - Наташа! } \\
\text { [P] - Пойдем отююда! } \\
\text { [A] - Где моя сумка? }\end{array}$ & $\begin{array}{l}\text { - Wstawaj! Możesz iść? } \\
\text { - Chodźmy stąd! } \\
\text { - Gdzie moja torebka? }\end{array}$ \\
\hline 3. & {$[47: 43]$} & $\begin{array}{l}\text { [G] - Вставай! Вставай! } \\
\text { [S] - Ой, больно! Рука! } \\
\text { [G] - Вставай! Вставай! }\end{array}$ & $\begin{array}{l}\text { - Boli! Ręka! } \\
\text { - Wstawaj! }\end{array}$ \\
\hline 4. & {$[49: 35]$} & $\begin{array}{l}\text { [AG] - Пошевели пальцами на руках } \\
\text { и на ногах. Не болит? }\end{array}$ & $\begin{array}{l}\text { - Porusz palcami u rąk i nóg. } \\
\text { Nie boli? }\end{array}$ \\
\hline
\end{tabular}

\footnotetext{
${ }^{5}$ Przytoczona w tabelach polska wersja będzie wykorzystana w analizie rozwiązań translatorskich w kolejnym paragrafie.
} 


\begin{tabular}{|l|l|l|} 
[K] - Нет. & - Nie. \\
[AG] - Хорошо. Делай вдох, глубокий. & - Świetnie! Teraz głęboki wdech. \\
Медленно. Не больно? Тихо, тихо, & Powoli. W porządku? Wstań. \\
тихо. Вставай. Вставай, вставай. & Powolutku. Nie kręci się w głowie? - \\
Вставай тихонько, тихонько вставай. & Dobrze. \\
Голова не кружится? Хорошо! & \\
\hline
\end{tabular}

Wśród przytoczonych replik pojawiają się zawołania osób, m.in. córki lekarza (Ксюша!), nieznajomej kobiety (Hamama!), liczne powtórzenia z prośbą o pomoc, ratunek (Ой, мамочка, спаси!) lub kategoryczne żądania podjęcia lub zaniechania działań (Пойдем отсюда! Давай вставай!). Cechą filmu katastroficznego jest dynamika akcji, rozwijające się w bardzo szybkim tempie wydarzenia, wyścig z czasem osób uwikłanych w katastrofę i usiłujących za wszelką cenę wygrać z żywiołem lub przynajmniej przed nim uciec. Na płaszczyźnie językowej wyraża się to w oszczędnym doborze środków stylistycznych, w operowaniu krótkimi zdaniami lub równoważnikami zdań, poprzez użycie czasowników operacyjnych. Język służb zaangażowanych $\mathrm{w}$ akcje ratownicze jest nacechowany dyrektywnością i klarownością wydawanych poleceń. Dominują wypowiedzi z funkcją impresywną, obecna jest także leksyka niecenzuralna:

Tabela 2. Komunikaty służb ratowniczych i rozmowy obsługi metra

\begin{tabular}{|c|c|c|c|}
\hline $\mathrm{Nr}$ & $\begin{array}{l}\text { Kod czasowy } \\
\text { wejścia }\end{array}$ & Wersja rosyjska & Polska wersja lektorska \\
\hline 1. & {$[51: 25]$} & $\begin{array}{l}\text { - Связи с ним нет. Чёрт знает, что! } \\
\text { - Валера! Все три насоса на полную } \\
\text { мощность! }\end{array}$ & $\begin{array}{l}\text { - Nie mamy kontaktu! Co się dzieje, } \\
\text { do cholery?! } \\
\text { - Walery! Wszystkie trzy pompy na } \\
\text { pełną moc! }\end{array}$ \\
\hline 2. & [51:37] & $\begin{array}{l}\text { - Вода в тоннеле. } \\
\text { - Отключай контактный рельс. } \\
\text { - А назад он на чём поедет? Сейчас } \\
\text { дойдет до последнего вагона, тогда и } \\
\text { спросим, в чем дело. } \\
\text { - 42-й! Ответьте дежурному! Ну, чё там } \\
\text { 42-й, а? } \\
\text { - Ну, автоблокировка сработала, } \\
\text { наверное. }\end{array}$ & $\begin{array}{l}\text { - W tunelu jest woda. } \\
\text { - Wyłącz szynę zasilającą. } \\
\text { - To jak się wycofa? Niech dojdzie do } \\
\text { ostatniego wagonu, zapytamy, co jest. } \\
\text { - 42! Zgłoś się! Co z tobą 42!? } \\
\text { - Chyba blokada automatyczna. }\end{array}$ \\
\hline 3. & [53:40] & $\begin{array}{l}\text { - Слышите? - Бегом, быстро! Эй, } \\
\text { мужик, открывай срочно! Чего ты }\end{array}$ & - Tu 17-ty, jestem gotów! Ruszaj! \\
\hline
\end{tabular}




\begin{tabular}{|c|c|c|c|}
\hline & & $\begin{array}{l}\text { телишься, давай бегом! } \\
\text { - 17-й на месте, готов к движению! } \\
\text { Пошел! Придурки! }\end{array}$ & $\begin{array}{l}\text { Ruszył w odwrotną stronę! } \\
\text { Debil! }\end{array}$ \\
\hline 4. & [56:32] & $\begin{array}{l}\text { - Как только 17-й выйдет из зоны } \\
\text { подстанции, отключай контактный } \\
\text { рельс. } \\
\text { - Понял вас! } \\
\text { - Ты представляешь, что сейчас там } \\
\text { творится? Ну что, романтика, диггер? }\end{array}$ & $\begin{array}{l}\text { - Kiedy 17-ty wyjedzie ze strefy } \\
\text { podstacji, odłącz napięcie od szyny } \\
\text { zasilającej! } \\
\text { - Zrozumiałem! } \\
\text { - Wiesz, co się tam teraz dzieje? } \\
\text { Nareszcie coś dla ciebie, poszukiwaczu! }\end{array}$ \\
\hline 5. & [01:00:25] & $\begin{array}{l}\text { - Шевченко? Шевченко? Ты вырубил } \\
\text { контактный рельс? } \\
\text { - Да. } \\
\text { - Тогда какого хрена у меня аварийка } \\
\text { горит? } \\
\text { - Пока не знаю. }\end{array}$ & $\begin{array}{l}\text { - Szewczenko! Odłączyłeś szynę } \\
\text { zasilającą? } \\
\text { - Tak! } \\
\text { - To dlaczego, kurde, pali mi się } \\
\text { lampka awaryjna? } \\
\text { - Nie wiem. }\end{array}$ \\
\hline
\end{tabular}

Powyższe repliki potwierdzają obecność zdań rozkazujących w funkcji poleceń służbowych (Отключай контактный рельс!, Ответьте дежурному!, Открывай срочно!, Давай бегом!), zarazem zdradzają zdenerwowanie pracowników, mających problem z ustaleniem źródła zalania tunelu i utrzymaniem ciągłości połączenia $\mathrm{z}$ podwładnymi. Wskazują na konieczność podjęcia natychmiastowych działań. Obecne jest słownictwo techniczne (контактный рельс, автоблокировка, насос на полную мощность). $\mathrm{W}$ fabułę filmu, oprócz wątku uwięzionych w tunelu pasażerów i prowadzonej akcji ratowniczej, wpleciony jest trzeci wątek. Ujawnia się on w scenach z udziałem członków rodziny i znajomych, silnie zaniepokojonych o los swoich bliskich uwięzionych pod ziemią i usiłujących za wszelką cenę nawiązać z nimi kontakt telefoniczny lub uzyskać informacje na ich temat od służb ratowniczych.

Tabela 3. Rozmowy członków rodziny z osobami koordynującymi akcją ratunkową [zastosowane skróty: I: Irina (matka Kseni), K: koordynator służb]

\begin{tabular}{|c|c|c|}
\hline $\begin{array}{l}\text { Kod } \\
\text { czasowy } \\
\text { wejścia }\end{array}$ & Wersja rosyjska & Polska wersja lektorska \\
\hline$[01: 39: 56]$ & $\begin{array}{l}\text { [І] - Подождите. У меня там муж и дочь. } \\
\text { Можно хоть как-то что-то о них узнать? Хоть } \\
\text { что-нибудь. } \\
\text { [К] - Из тоннеля все вышли. Пострадавших } \\
\text { увезли в больницу. }\end{array}$ & $\begin{array}{l}\text { - Tam jest mąż i córka. Chciałabym się } \\
\text { czegokolwiek dowiedzieć. } \\
\text { - Wszyscy wyszli z tunelu. Rannych } \\
\text { odwieziono do szpitala. }\end{array}$ \\
\hline
\end{tabular}




\begin{tabular}{|c|c|}
\hline $\begin{array}{l}\text { [I] - В какую? } \\
\text { [K] - В разные. Ищите информацию в } \\
\text { списках. } \\
\text { [I] - Я уже в списках, я уже читала, их нет в } \\
\text { списках. } \\
\text { [K] - Списки уточняются. } \\
\text { [I] - У них мобильники не отвечают. } \\
\text { [K] - Дождитесь. } \\
\text { [I] - А погибшие там есть? Хоть что-то } \\
\text { можно узнать о погибших? } \\
\text { [K] - У меня нет информации. } \\
\text { [I] - Ну как нет? } \\
\text { [K] - Да, я, правда, не знаю. }\end{array}$ & $\begin{array}{l}\text { - Którego? } \\
\text { - Proszę sprawdzić na listach. } \\
\text { - Już przeglądałam. Nie ma ich. } \\
\text { - Listy są uaktualniane. } \\
\text { - Trzeba czekać. } \\
\text { - Są ofiary śmiertelne? } \\
\text { - Nie mam takich informacji. } \\
\text { - Jak to? } \\
\text { - Naprawdę nie wiem. }\end{array}$ \\
\hline
\end{tabular}

W strukturze dialogowej pojawiają się wypowiedzi silnie nacechowane emocjonalnie. Powyższy przykład ilustruje napięcie komunikacyjne pomiędzy zrozpaczoną matką i żoną a koordynatorem służb. W wersji dźwiękowej jest ono wzmocnione silnie podniesionym głosem kobiety i wyważonym tonem odpowiedzi mężczyzny.

\section{ANALIZA ROZWIĄZAŃ TRANSLATORSKICH}

Film jako tekst multimodalny (Baldry i Thibauld; Szarkowska, Forms; Post; i in.), polisemiotyczny (Delabastita; Bogucki 77) wymaga w sytuacji interlingwalnego przekładu dokonania operacji wyłącznie na materii językowej przy jednoczesnej koncentracji uwagi tłumacza na wszystkich kodach semiotycznych, obecnych w danym filmie, tj. jego warstwie werbalnej (dialogi filmowe), wizualnej (obraz), dźwiękowej (muzyka, odgłosy pracujących sprzętów, wybuchy, grzmoty i inne efekty dźwiękowe). Jak słusznie zauważa Teresa Tomaszkiewicz, tłumacz, nie mogąc ingerować w warstwę wizualną filmu, ma za zadanie dokonać transferu międzyjęzykowego (Tomaszkiewicz 97). Nasuwa się więc wniosek, że skoro dominujący jest obraz (wraz z dźwiękiem), który pozostaje niezmienny i co jest bardzo istotne - jest $\mathrm{w}$ filmie katastroficznym bardzo sugestywny - $\mathrm{i}$ jest on składnikiem inwariantu intersemiotycznego, to znaczy, że zasadniczo w przekładzie ten inwariant jest zawsze w jakimś stopniu zachowany. Nie oznacza to jednak, że w tym samym. Tłumacz filmowy zmuszony jest dokonać kondensacji i skracania treści w wersji lektorskiej. Dlatego, oceniając rozwiązania translatorskie, należy zwrócić szczególną uwagę na integrację przetłumaczonych dialogów 
z innymi kodami dzieła filmowego. Konieczne jest odwołanie się do okoliczności funkcjonowania wersji lektorskiej. Jej obecność w tłumaczonym filmie powoduje, że dialogi filmowe docierają do widza drogą podwójną: $\mathrm{w}$ wersji tłumaczonej oraz $\mathrm{w}$ wyciszonej wersji oryginalnej. Jak słusznie zauważa Marek Hendrykowski, ,projekt odbioru zakłada w tym przypadku [filmu z wersją lektorską - MMK] z reguły ścisłą korelację obu nurtów realizowania się ekranowych wypowiedzi, rozdzielonych z konieczności na: 1) strefę transmisji brzmień i 2) strefę transmisji znaczeń" (Hendrykowski 90). Ten fakt determinuje sposób tłumaczenia lektorskiego. Na podstawie przeprowadzonej analizy w pierwszej kolejności należy odnotować częste rezygnacje tłumaczki $\mathrm{z}$ powtórzeń leksemów: na 45 takich powtórzeń w tekście oryginalnym przypada jedynie 16 powtórzeń w przekładzie. Dotyczy to zarówno kluczowego dla filmu wyrazu woda, czasowników operacyjnych (typu wstawaj!) (przykład 3 z tabeli 1), jak i form adresatywnych (np. Ksiusza, Natasza - przykład 1. i 2., tabela 1). W przypadku tych ostatnich znamienne jest to, że ich ewentualne użycie zdublowałoby wersję oryginalną, $w$ przekładzie te imiona nie zmieniają bowiem swojej warstwy brzmieniowej. Tłumaczka zmniejszyła redundancje wypowiedzi słownych w stosunku do paralelnych treści przekazywanych za pośrednictwem obrazu. Regularnie korzysta z zabiegów kondensacji informacji. Przykład z tabeli 3: zrozpaczona matka Kseni próbuje uzyskać informacje o ofiarach: A погибшие там есть? Хоть что-то можно узнать о погибших? W przekładzie pojawia się krótki komunikat: Sa ofiary śmiertelne? Ta forma zadanego pytania implicytnie wskazuje na potrzebę uzyskania jakichkolwiek informacji na ich temat. Podobnie w przykładzie 6. (tabela 3.): rosyjski komunikat: Ваша задача - дойти. Если не дойти, то максимально приблизиться к месту прорыва, оценить обстановку otrzymuje w przekładzie skróconą formułę Wasze zadanie to podejść jak najbliżej wyrwy i ocenić sytuację. Tłumaczka przekazała natomiast leksykę niecenzuralną (12 użyć), w tabeli nr 1 podano przykład użycia - P3) jako leksykalne wzmocnienia skrajnych emocji bohaterów uwikłanych w walkę z żywiołem lub usiłujących wydostać się z zalanego metra. Wydawane zwięzłe komunikaty o wysokiej sile dyrektywności otrzymują w przekładzie naturalnie brzmiące polskie ekwiwalenty, np. Коней связи! - Rozłaczam się! Są one optymalnie dostosowane do sytuacji komunikacyjnej widocznej na ekranie: He беpem. - Nie ma zasięgu (o telefonie komórkowym w bunkrze metra); А у меня деньги кончились. - Mam zero na koncie. Te zabiegi, precyzujące kontekst użycia tłumaczonych wypowiedzi, ułatwiają odbiór treści werbalnych, ich naturalne brzmienie pozytywnie wpływa na precyzyjny przekaz komuni- 
katów. Napięcie w filmie, budowane za pomocą sugestywnych obrazów i dźwięków (muzyki, napierającej wody, rozpędzonego w podziemiach wagonu metra $\mathrm{i}$ in.), absorbujące percepcję wzrokową widzów, nie sprzyja wzmożonej koncentracji na warstwie werbalnej filmu. To kolejny argument za słusznością podjętych przez tłumaczkę rozwiązań, prowadzących do kondensacji tłumaczonego tekstu.

\section{IMPLIKACJE DYDAKTYCZNE}

Zaproponowane podejście deskryptywne w postaci analizy dwutekstu, skoncentrowanej na wskazaniu cech gatunkowych rosyjskiego filmu katastroficznego i sposobu ich przekazania w polskiej wersji lektorskiej, wyznacza preskryptywny kierunek działań w obszarze dydaktyki przekładu filmowego na poziomie uniwersyteckim. Te działania mają na celu ustalenie reguł optymalnego przekładu $\mathrm{z}$ uwzględnieniem cech gatunkowych thumaczonego filmu. Powstaje pytanie, jakie konkretne działania, w jakim zakresie i na jakich etapach pracy nad przekładem powinny być podjęte, aby przetłumaczony film zachował inwariant intersemiotyczny, decydujący o jego tożsamości gatunkowej. Ustalenie cech gatunkowych filmu jest etapem przygotowawczym do właściwego tłumaczenia. Kluczowa wydaje się uważna analiza semiotyczna i strukturalna tekstu oryginalnego, wymagająca od studentów podstawowej wiedzy filmoznawczej i językoznawczej w zakresie konwencji gatunkowych. Są to działania tym bardziej pożądane, że z reguły w filologicznych programach uniwersyteckich nie ma odrębnych zajęć poświęconych tematyce genologii filmowej. Proponuje się ustalenie głównej osi fabuły, uważną analizę powiązanych z sobą wątków oraz struktury prowadzonej narracji. Niezbędne jest uważne obejrzenie filmu (niekiedy nawet kilkakrotne), ze zwróceniem uwagi na tekst dialogowy oraz współistniejącą z nim warstwę wizualną. Taka analiza pomoże ustalić zestaw cech inwariantnych, typowych dla danego gatunku filmowego. Samo pojęcie inwariantu zakłada pewną selekcję materiału, konieczną z uwagi na ograniczenia czasowe i uwarunkowania techniczne wersji lektorskiej (nakładanie tłumaczonej wersji językowej na wyciszoną oryginalną). Istotne jest jednak, aby dokonując selekcji materiału językowego pozostawić w wersji tłumaczonej treści relewantne dla semantyki thumaczonego gatunku. Etap selekcji tekstu werbalnego jest kluczowy, a przy tym niełatwy. Praktyka dydaktyczna pokazuje, że skracanie treści wymaga sprawności językowych, analitycznych, precyzji myślenia i formułowania wypowiedzi. Przy podejmowaniu decyzji trans- 
latorskich przez studentów warto im uświadomić, że w odbiorze przekładu filmowego mamy do czynienia z sytuacją nietypową. Mianowicie jego odbiorcy - oprócz przygotowanej dla ich potrzeb językowych wersji tłumaczonej - bardzo często mają dostęp do wersji oryginalnej, tylko nieco wyciszonej. Wymóg kondensacji tekstu sprawia, że studenci powinni umieć (i nie bać się) zastosować transformacje semantyczno-leksykalne, sprzyjające takim modyfikacjom: opuszczenia, rozwinięcia logiczne, kompensacje, generalizacje i konkretyzacje znaczeń, a nawet przekształcenia całościowe ${ }^{6}$.

\section{PODSUMOWANIE}

Przeprowadzone badania stanowią nową propozycję dla podniesienia jakości oraz atrakcyjności akademickiej dydaktyki przekładu na potrzeby kinematografii. Istotne jest holistyczne podejście do dydaktyki tłumaczenia filmowego, tzn. uwzględnienie na poszczególnych etapach jego procesu nie tylko wymogów stosowanej techniki tłumaczenia filmowego, ale także cech gatunkowych filmów. Tym bardziej że gatunek filmowy jest operacyjną, funkcjonalną jednostką taksonomii filmowej, opartą na konwencjach społecznych i dzięki nim jest społecznie rozpoznawalny. Cechy dystynktywne gatunku wyznaczają jego funkcję w kulturze odbioru. Jeżeli zatem widz otrzymuje w opisie filmu informację, że produkcja, którą zamierza obejrzeć w kinie lub warunkach domowych, należy np. do gatunku filmu katastroficznego, to zadaniem tłumacza jest opracowanie tłumaczenia $\mathrm{z}$ zachowaniem cech relewantnych dla tego gatunku.

\section{BIBLIOGRAFIA}

Adamowicz-Grzyb, Grażyna. Ttumaczenia filmowe w praktyce. FORTIMA Tłumaczenia - Edukacja-Media, 2013.

Baldry, Anthony, i Paul J. Thibault. Multimodal Transcription and Text Analysis. Equinox, 2006.

Bogucki, Łukasz. Areas and Methods of Audiovisual Translation Research. Peter Lang, 2013.

„Metodologia badań w przekładzie audiowizualnym”. Metodologie językoznawstwa. Od dialektologii do dialektyki, red. Piotr Stelmaszczyk, Wydawnictwo Uniwersytetu Lódzkiego, 2015, ss. 73-87.

\footnotetext{
${ }^{6}$ Dokładne omówienie wymienionych typów transformacji w pracy M. Mocarz Predykatywy leksykalne w konfrontacji przekładowej.
} 
Chmiel, Agnieszka, i Iwona Mazur. Audiodeskrypcja. Wydział Anglistyki UAM, 2014. AMUR Adam Mickiewicz University Reopsitory, http://repozytorium.amu.edu.pl:8080/bitstream/ 10593/12861/1/ Audiodeskrypcja_Chmiel_Mazur_2014.pdf. Dostęp 12.01.2020.

Delebastita, Dirk. „Translation and Mass Communication: Film and TV Translation as Evidence of Cultural Dynamics". Babel, vol. 35(4), 1989, ss. 192-218.

Díaz-Cintas, Jorge. „Audiovisual Translation in the Third Millennium”. Translation Today: Trends and Perspectives, red. Gunilla Anderman, i Rogers Margaret, Multilingual Matters, 2003, ss. 192-204.

Gambier Yves, i Henrik Gottlieb, redaktorzy. (Multi)Media Translation: Concepts, Practices and Research. John Benjamins, 2001.

Garcarz, Michał. Przektad slangu w filmie. Tertium, 2007.

Gottlieb, Henrik. „Subtitling - A New University Discipline”. Teaching Translation and Interpreting. Training. Talent and Experience, red. Cay Dolleru i Anne Loddegaard, John Benjamins, 1992, ss. 161-170.

Hendrykowski, Marek. Drugie wejrzenie. Analizy i interpretacje. Wydawnictwo Naukowe UAM, 2018.

Hołobut, Agata, i Monika Woźniak. Historia na ekranie. Gatunek filmowy a przekład audiowizualny. Wydawnictwo Uniwersytetu Jagiellońskiego, 2017.

Kaczmarek, Anna. „Dydaktyka przekładu audiowizualnego na filologii romańskiej od podstaw: metody, treści, propozycje rozwiązań”. Między Oryginatem a Przekładem, vol. 19, nr 1-2, 2013, ss. 67-84.

Loska, Krzysztof. „Gatunek filmowy”. Stownik filmu, red. Rafał Syska, Krakowskie Wydawnictwo Naukowe, 2010, ss. 72-73.

McLoughlin, Laura Uncalcaterra. „Subtitling and the Didactics of Translation”. Global Trends in Translator and Interpreter Training, red. Severine Hubscher-Davidson i Michał Borodo, Bloomsbury Academics, 2012, ss. 127-143.

Mocarz, Maria. Predykatywy leksykalne w konfrontacji przekładowej. Towarzystwo Naukowe KUL, 2005.

Moine, Raphaëlle. Cinema Genre. Wiley-Blackwell, 2008.

Post, Michał. Film jako tekst multimodalny. Założenia i narzędzia jego analizy. Wydawnictwo Wyższej Szkoły Filologicznej, 2017.

Reinart, Sylvia. Untertitelung in einem Synchronistionsland. Peter Lang, 2018.

Szarkowska, Agnieszka. „Przekład audiowizualny w Polsce - perspektywy i wyzwania”. Przektadaniec, vol. 22, 2008, ss. 8-25.

Szarkowska, Agnieszka. Forms of Address in Polish-English Subtitling. Peter Lang, 2013.

Tomaszkiewicz, Teresa. Przektad audiowizualny. Wydawnictwo Naukowe PWN, 2006.

\section{FILMOGRAFIA}

Metro. Reżyseria Anton Miegierdiczew. Tekst polski Krystyna Łozowska, 2010 (2018 - data emisji w TVP Kultura). 


\section{GATUNEK FILMOWY JAKO OBIEKT PRZEKŁADU - IMPLIKACJE DYDAKTYCZNE}

\section{Streszczenie}

Punktem wyjścia w niniejszych badaniach jest hipoteza, że przekład filmowy jest wewnętrznie zróżnicowany nie tylko poprzez stosowane techniki (wersja lektorska, dubbing, napisy), ale także poprzez konkretny gatunek filmowy, analogicznie do istniejących typologii przekładu tekstu werbalnego ( $\mathrm{tj}$. literackiego, użytkowego, specjalistycznego). Przekład zatem różnych gatunków filmowych wymaga od tłumacza filmowego odrębnego podejścia do danego gatunku, odmiennego sposobu strategicznego myślenia, wnikliwej analizy materiału filmowego, uważnego spojrzenia na słowo, obraz i dźwięk w przekładzie jako komponenty estetyki i budulce schematów fabularnych filmu. Tak postawiona hipoteza wyznaczyła następujące zadania w kontekście dydaktyki przekładu filmowego: 1) ustalenie najważniejszych cech gatunkowych filmu, będących podstawą tzw. inwariantu intersemiotycznego, który powinien być odtworzony w przekładzie, 2) analizę istniejących rozwiązań translatorskich, zogniskowanej na zachowaniu takiego inwariantu z wykorzystaniem techniki wersji lektorskiej, 3) propozycję zastosowań wytycznych gatunkowych w akademickiej dydaktyce przekładu filmowego.

Słowa kluczowe: gatunek filmowy; film katastroficzny; dydaktyka przekładu filmowego.

\section{GENRE CINEMA AS AN OBJECT OF TRANSLATION: IMPLICATIONS FOR TEACHING}

\section{S u m m a ry}

The starting point for this research is the hypothesis that film translation is internally varied by its very nature, not only by the techniques used (voice-over, dubbing, subtitles), but also by a particular film's genre, by analogy with the current translation typologies based on the criterion of a specific genre for a typical verbal text (i.e. literary, functional, specialist). Therefore, the translation of different film genres requires from the film translator a different approach to a given genre, a different way of strategic thinking, a thorough analysis of film material (verbal and visual), a close look at the word, picture and sound in translation as the components of aesthetics and the building blocks of the plot patterns of the film. These are tasks for the didactics of film translation. Such a hypothesis sets out the following objectives: 1) determining the linguistic invariant of the text with a set of formal-linguistic features, which is indicative of a given genre and which should be respected in translation; 2) analysing translation procedures focused on the level of maintaining the invariant in translation; 3) a proposal of practical applications in the academic didactics of film translation.

Key words: film genre; disaster film; didactics of film translation. 